\title{
Simone Poggi's Neo-Latin Fables: a Jesuit in the Footsteps of Phaedrus
}

\author{
José C. MiRALles MALDONADO
}

The Italian Jesuit Simone Maria Poggi (1685-1749) was an outstanding member of the "Academy of Arcadia", where he was known as Nimesius Ergaticus. He wrote ten books of Latin fables under the inspiration of Phaedrus. These apologues were published posthumously by Giuseppe Boero in 1883. In their composition, the Jesuit from Bologna used iambic senarii, the metre employed by Phaedrus, and tried to adapt the Roman fables to his time and circumstances. In this article, I will offer an overview of Poggi's Latin fables paying special attention to his prologues, epilogues and programmatic fables, in which, following Phaedrus' example, our poet gives many clues about his sources and literary interests along with autobiographical issues. I will focus my research on Poggi's relationship with his predecessors and on his conception of the fable not only as a literary subgenre but also as a very useful educational tool. Summing up, my aim will be to show that Poggi's fable collection constitutes a remarkable and curious product of Phaedrus' influence on Neo-Latin literature in the eighteenth century.

In 1883 Giuseppe Boero posthumously published the collection of Latin fables that the Jesuit Simone M. Poggi had composed in the first half of the eighteenth century under the inspiration of Phaedrus. ${ }^{1}$ I dedicate the present work to the analysis of this fable collection. Specifically, I will focus my research on the influence that the Roman fabulist had on Poggi's Neo-Latin fables. With the exception of Carlo Filosa's work, ${ }^{2}$ in my opinion, there has been a lasting and undeserved silence on this author that I will try to compensate with my study.

\section{The Author}

The Jesuit Simone Maria Poggi, who was born in Castel Bolognese in 1685 and died in Faenza in 1749, was a prominent member of some

${ }^{1}$ Simonis M. Poggi e Societate Iesu seu Nimesii Ergatici pastoris Arcadis fabularum Aesopiarum libri decem (Florentiae, 1883).

${ }^{2}$ Cf. C. Filosa, La favola e la letteratura esopiana in Italia dal Medio Evo ai nostri giorni (Milano, 1952), 280-285. 
renowned poetic academies of the eighteenth century such as the "Academy of Arcadia" (Colonia Renia), where he was known as Nimesius Ergaticus. ${ }^{3}$ Our author combined a prolific activity as poet with his academic work as professor of Grammar and Rhetoric in different schools of the Society of Jesus. Thus, he worked as a teacher successively in cities such as Piacenza, Bologna, Brescia, Padova, Parma and Faenza, where he spent the last years of his life. ${ }^{4}$ Besides cultivating poetry in Latin and Italian, he achieved great recognition as an author of mythological and historical tragedies like Idomeneo, Antenore, Agricola, etc., pastoral plays (L'Erminio di Frigia) and even comedies (Il Tamburlano), which were recited with great success in the schools of the Jesuits. ${ }^{5}$

Most of his vast literary production (including his ten books of Latin fables) remained unpublished, although some manuscripts of his works are preserved (especially, in Roman libraries such as the Biblioteca Angelica or the Fondo Gesuitico from the Biblioteca Nazionale Centrale), many of which are autographs. ${ }^{6}$

\section{Why Were his Fables Not Published During his Life?}

Poggi's Latin fables, composed in the first half of the eighteenth century, may have enjoyed a certain circulation among Italian poets and intellectuals of this period, although they were not published until 150 years later.

${ }^{3}$ An introduction to the great significance that the "Accademia dell'Arcadia" had in Italian poetry of the Settecento and, in particular, an overview of the role played in this field by the Bolognese Academy (the so-called Colonia Renia) can be read in the works of M. Saccenti (ed.), La Colonia Renia. Profilo documentario e critico dell'Arcadia bolognese (Milano, 1988); S.M. Dixon, Between the Real and the Ideal. The "Accademia degli Arcadi" and its Garden in Eighteenth-Century Rome (Newark, 2006); B. Alfonzetti, "L'Accademia dell'Arcadia", in Il contributo italiano alla storia del pensiero. Letteratura (Roma, 2018), 327-332.

${ }^{4}$ An overview of Poggi's life and literary work can be read in M. Turrini, "Poggi, Simone Maria", Dizionario Biografico degli Italiani, vol. 84 (Roma, 2015), 479-481. See also G. Fantuzzi, Notizie degli scrittori Bolognesi, vol. 7 (Bologna, 1789), 74-79; and C. Sommervogel, Bibliothèque de la Compagnie de Jésus, vol. 6 (Bruxelles - Paris, 1890-1900), 917-919.

5 On Poggi's dramatic works, see the recent study by R. Salsano, Poetica drammaturgica primosettecentesca in Simone Maria Poggi (Roma, 2009).

${ }^{6} \mathrm{Cf}$. Turrini 2015 (as in n. 4), 481. We are referring to the following manuscripts: Biblioteca Angelica, ms. 2082 and Biblioteca Nazionale Centrale Vittorio Emanuele II, Fondo Gesuitico, ms. 1-6, 8-12, 14-16, 43, 58-60, 62-64 and 81. A brief description of these codices can be read on the Manus online website. 
The editor, G. Boero, says that he has two manuscripts: one autograph, dated $1748,{ }^{7}$ and the other copied by a different hand but corrected by the author himself, which he will take as a basis for his edition:

Duos prae manibus habeo codices. Primus quidem auctoris manu omnino descriptus [...]. Alter codex aliena quidem manu exscriptus, sed ab auctore hac illac emendatus, et in meliorem ordinem redactus est, omissis quibusdam fabulis, quae iam antea ipse reiecerat. Hunc autem numeris omnibus absolutum et ab auctore diligenter recognitum et probatum typis evulgandum, ut par erat, elegi. ${ }^{8}$

As far as we know, none of these codices is preserved today among those attributed to the Jesuit from Bologna. Boero blames Poggi's modesty and lack of self-confidence for the fact that these fables were not published during his lifetime. ${ }^{9}$ Indeed, it seems that the Jesuit was a tremendous perfectionist and accepted with difficulty negative criticism of his work. This feature of his character led him, for instance, to reject the authorship of his tragedy Idomeneo (1721), considering that it had been published without his permission and without including the many modifications that he intended to make to the text. ${ }^{10}$ His attitude towards the publication of his fables is also, at least, ambiguous. On the one hand, thanks to the testimony of some of his friends, like Fantuzzi, we know that he planned to publish his fables; ${ }^{11}$ however, in the Praefatio auctoris that opens his work, despite the abundant appeals to the readers throughout his work, he underlines his intention not to publish them during his life (5-9):

${ }^{7}$ Cf. Poggi 1883 (as in n. 1), v: "Ego Simon Maria Poggi [...] annos iam septemdecim in hac urbe degens, annumque aetatis meae nunc agens sexagesimum tertium, volumen hoc mea manu scribebam anno domini MDCCLVII". As you can see, Boero affirms that this manuscript was written in 1757; but this is, obviously, a mistake, because Poggi says that he was 63 years old and that he had lived for seventeen years in Faenza by then, where he had arrived in 1731. Therefore, the correct date is 1748 .

${ }^{8}$ Poggi 1883 (as in n. 1), v-vi.

${ }^{9}$ Poggi 1883 (as in n. 1), iii: "plura scripsit elegantissime tum soluta tum ligata oratione; nihil tamen ex iis pro sua animi demissione et modestia passus est unquam, dum viveret, in lucem edi."

${ }^{10}$ Cf. Fantuzzi 1789 (as in n. 4), 75; and M. Turrini 2015 (as in n. 4), 481.

${ }^{11}$ Fantuzzi 1789, (as in n. 4), 77: "Godevano queste favole la predilezione del loro autore, che nell'anno stesso della sua morte ne meditava la stampa." 


\begin{abstract}
Latuit hactenus
in nostris clausa et obserata scrimniis;

Ac ni fur rapiat, vel me amentia ceperit, dum vivo, ibi latebit clausa in posterum, centumque, ut ante, ibi servata clavibus. ${ }^{12}$
\end{abstract}

In the final lines of the preface, the poet will identify himself with the greedy men mentioned by Horace in his first satire (Sat. 1.1.64-67 and 94-100), in order to relate his "avaritia" to theirs. ${ }^{13}$

We know that Poggi himself read and circulated his fables among his friends, although he did not always find the welcome he expected. There are numerous lines dedicated to critics who questioned some aspects of his work, a clear symptom of his difficulty in accepting the comments and criticisms against his fables. The Jesuit often uses the prologues of his fable books to attack his critics and to defend himself from their accusations. ${ }^{14}$ Thus, in the extensive prologue to book 2 (133 verses) he explains how his book 1 circulated among his friends, obtaining unanimous applause until it reached - Poggi says - the hands of a "cruel grammarian", who inflicted serious damage on it with his attacks. ${ }^{15}$ The grammarian, to whom Poggi refers, reproaches him, above all, for three inconsistencies: 1) that he calls his fables Aesopic, even though they are all of his own invention; 2) that, being a member of the Academy of Arcadia, he dedi-

12 Poggi 1883 (as in n. 1), 1: "[My Aesopic treasure] was until this moment hidden and locked up in my desk; and unless a thief steals it or madness takes hold of me, as long as I live, it will remain there hidden and concealed forever and, as before, kept under a hundred keys."

${ }^{13}$ In this poem, Horace's poetry functions as a hypotext of Poggi's fables. See also Hor. Carm. 2.14.26.

${ }^{14} \mathrm{We}$ are dealing with a collection of poems, that is, with fiction, and we should not equate the person of the poet with his creation. Therefore, Poggi's statements should not be interpreted exclusively in an autobiographical sense, as they can also serve to construct the fictional persona of the fable writer, following the example of Phaedrus himself. In the same vein, some modern scholars such as E. Champlin - in "Phaedrus the Fabulous", The Journal of Roman Studies 95 (2005), 97-123 - think that Phaedrus' prologues and epilogues do not necessarily reflect the real world and should therefore not be read as a biography of the poet.

15 The metaphor of wounds to refer to attacks on the integrity of the literary text has a great tradition. Paradigmatic and well known is the passage from Lipsius' Somnium, where Cicero addresses the Senate to lament the damage, the wounds inflicted on his texts by the correctors of the Renaissance. Cf. C. Matheeussen, C.L. Heesakkers, Two Neo-Latin Menippean Satires. Justus Lipsius, Somnium. Petrus Cunaeus, Sardi venales (Leiden, 1980), 44-46. 
cates himself to cultivating the modest genre of fable; and, finally, 3) that he affirms in the prologue to book 1 (1 Prol. 2) that he has "polished up" in iambic senarii the fabulistic material from Phaedrus, whereas, in fact, all fables (at least, those in book 1) are original.

Already from the prologue to book 2, Poggi shows himself to be very hard on his critics, and repeatedly refers to them as canes (al)latrantes ("barking dogs"). But, in his own words, he is not afraid of the barks of his critics and does not hesitate to consider his book metaphorically as a stone thrown in the face of envious dogs (123-126):

Et huic dein libro noster allatret canis.

Tibi hic novum sit pignus obsequii mei,

et invido sit idem nostro ei cani

in allatrantis os novus impactus lapis. ${ }^{16}$

The terms he uses to designate his critics are diverse: censor, criticus, grammaticus, etc. Others, like the term nasutus, seem to go back to Phaedrus. ${ }^{17}$ Some words like scioli or obtrectatores have an evident pejorative value. ${ }^{18}$

Our poet shows himself defiant not only with his critics but also with his emulators, especially with those who claimed to have composed Aesopic fables in iambic senarii, much more accomplished than his own. Thus, in Fable 3.15 (Iactator audientium in corona), after reworking the Aesopic apologue on the athlete that boasted of having established a new

16 Poggi 1883 (as in n. 1), 35. Poggi often uses the expression "me latrant canes" or something similar to allude to his critics' attacks; cf., among others, ibid., 82 (3 Poeta 16), 180 (6.20.103) and 246 (8.19.57). On this expression and its possible proverbial meaning, see A. Otto, Die Sprichwörter und sprichwörtlichen Redensarten der Römer (Leipzig, 1890), 69-70. Erasmus of Rotterdam includes among his adages (2337) the expression "canina facundia" to refer to those who use eloquence with the only purpose of swearing: cf. Erasmi Roterodami [...] Adagiorum Chiliades tres ac centuriae fere totidem (Basileae, 1513), f. 145v. Cf. R. Tosi, Dizionario delle sentenze latine e greche (Milano, 2017), n. 78.

${ }_{17}$ The term nasutus with the meaning of "sagacious, ill-willed critic" is frequent in Mart. Epigr. 12.37.1; 13.2.1. In Phaedrus it only appears in 4.7.1 ("Tu qui nasute scripta destringis mea") and there is still discussion whether nasute is here an adjective or an adverb. We can attest this controversy already among the first commentators of Phaedrus' fables: cf. P. Burmann (ed.), Phaedri [...] Fabularum Aesopiarum libri V [...] (Hagae-Comitum, 1718), 154.

18 The term sciolus (= "smatterer, sciolist") is only attested in late Christian authors, as Hier. Ep. 48.18; 58.5. 
record in the broad jump on the island of Rhodes (Aes. 33 Perry $=51$ Chambry $=203 \mathrm{Halm}),{ }^{19}$ our poet applies the morality of the story to his rivals, challenging them to stop underestimating his work and inviting them to bring their fables to light (18-24):

Iactator quilibet sibi scripta haec putet:

ast is prae reliquis, qui invenisse fabulas

se iactat nostris meliores, et optimis

Aesopum pariter perpolisse iambicis, quibus si nostri conferantur, sordium putens sint cumulus, nec opes tantas interim in lucem profert. Has proferat, et cedimus. ${ }^{20}$

To settle the issue with his rivals, Poggi may have decided to publish his fables at the end of his life, but he was unable to do so, as death came a few months after having finished the revision and collection of his fables (1749).

It is difficult to know why Poggi's fables were printed at the end of the nineteenth century. On the one hand, we know that Poggi was reluctant to publish his literary works during his lifetime. On the other hand, if we give credit to the words of the publisher, these fables fell into his hands by chance and, on reading them, Boero was amazed by the brilliance and elegance of his Latin style. He thought of publishing them, because, despite or precisely due to the discredit and abandonment of Latin in his time, he considered that these fables could be useful for young students:

Quum vero non pauca eius scripta in manus meas fortuito venerint, avidissime perlegi libellum, in quo decem libri Fabularum Aesopi-

${ }^{19}$ I quote the fables of the Collectio Augustana from the following editions: C. Halm (ed.), Fabulae Aesopicae collectae (Lipsiae, 1901); E. Chambry (ed., tr.), Esope. Fables (Paris, 1927); B.E. Perry, "An Analytical Survey of Greek and Latin Fables in the Aesopic Tradition", in Id., Babrius and Phaedrus (Cambridge, MA - London, 1965), 419-610.

${ }^{20}$ Poggi 1883 (as in n. 1), 81. It seems that the Jesuit has a specific case in mind, probably a rival poet who claimed to have composed better fables than his: "Let any presumptuous person consider that this fable was written for him, but, first of all, he who boasts of having composed better fables than mine and also of having polished up all Aesop with excellent iambic verses, to the point that mine, compared with his, is a rotten pile of rubbish; yet he never brings to light such treasures! Let him bring them out and I will withdraw." 
arum continebantur, miratusque eximium Latini stili nitorem et venustatem, iam tum animo conceperam eas omnes in publicam hominum lucem, ac praesertim studiosae iuventutis utilitatem evulgare. ${ }^{21}$

\section{Background and Chronology of Poggi's Fable Collection}

As published, Poggi's fable collection consists of ten books of fables written in iambic senarii. Following the example of Phaedrus, most of the books are headed by a prologue; some also have an epilogue or various programmatic fables with a metaliterary content (usually entitled Poeta), where he specifies his objectives and his poetic programme while reflecting on his work or on various aspects of his life.

The fables contained in each book vary both in number and extension: book 1 contains 35 fables, 2 (15), 3 (15), 4 (21), 5 (16), 6 (23), 7 (23), 8 (21), 9 (21) and 10 (23). The time of their composition is uncertain, although the author himself confesses that he began to write his collection during his youth. He then ordered and concluded it in his old age (Praefatio auctoris v. 1): "Quae iuvenis olim scripsi, collegi hic senex."

The author offers few clues about their chronology, except for some allusions to his stays in places like Brescia or Faenza, while he was composing his fables.

He concludes his collection with two appendices, where a total of 15 fables are collected (1: 10, and 2: 5) under the following title: Aesopiae fabulae nonnullae ex senariis Phaedri versibus in alia quaedam metra ab Nimesio Ergatico pastore Arcade olim traductae. In Appendix I, as the aforementioned title shows and as he declares in the poetic prologue to the reader, Poggi gathered together some fables from Phaedrus that he had adapted in other meters when teaching Rhetoric and Humanities at the Jesuit College in Brescia (1717-1719). ${ }^{22}$ In his own words, he had

${ }^{21}$ Poggi 1883 (as in n. 1), iii-iv. Whatever the main reason for their publication, Poggi's fables were transcribed and published by Giuseppe Boero, a Jesuit not very interested in literary matters, one year before his death. Cf. G. Martina, "Boero, Giuseppe", Dizionario Biografico degli Italiani, vol. 11 (Roma, 1969), 129-131.

${ }^{22}$ Cf. Poggi 1883 (as in n. 1), 307 (Nimesius idem lectori, 9-13): "Suis ex primis haec in metra has transtuli, / eram dum Brixiae, et ibi divi Antonii / frequenti tunc et inclyto in Collegio / coronae ingenti illustrium adolescentium / humaniores explanarem litteras." 
composed them as a school exercise for his young students and many of them had been accompanied by Italian verse translations. ${ }^{23}$ Likewise, in the prologue to the reader in Appendix II (Nimesius iterum lectori), he states that he found among his papers other fables that he had dictated to his students in Faenza to teach them how they could transform the metrical rhythm of a given poem. Those apologues are the ones he transmits to us in the last appendix. Next, I will offer a summary table of the Phaedrian fables reworked by Poggi in his appendices with reference to the new metres employed:

\begin{tabular}{|c|c|c|c|}
\hline App. I & Title & Source & New Metre \\
\hline 1 & Lupus et agnus & Phaedr. 1.1 & Hexameters \\
\hline 2 & Homo et coluber & Phaedr. 4.20 & Hexameters \\
\hline 3 & Passer et lupus ${ }^{24}$ & Phaedr. 1.9 & $\begin{array}{l}\text { Fourth Asclepiadean } \\
\text { strophe: Glyconic line } \\
\text { + First Asclepiadean }\end{array}$ \\
\hline 4 & Cervus ad fontem & Phaedr. 1.12 & $\begin{array}{l}\text { Fourth Asclepiadean } \\
\text { strophe: Glyconic line } \\
\text { + First Asclepiadean }\end{array}$ \\
\hline 5 & $\begin{array}{l}\text { Arbores in deorum } \\
\text { tutela }\end{array}$ & Phaedr. 3.17 & Stichic Asclepiadeans \\
\hline 6 & $\begin{array}{l}\text { Milvus sive accipiter } \\
\text { et columbae }\end{array}$ & Phaedr. 1.31 & $\begin{array}{l}\text { Phalecean } \\
\text { hendecasyllables }\end{array}$ \\
\hline 7 & $\begin{array}{l}\text { Canis per fluvium } \\
\text { carnem ferens }\end{array}$ & Phaedr. 1.4 & Elegiac distichs \\
\hline 8 & Rana rupta et bos & Phaedr. 1.24 & Elegiac distichs \\
\hline 9 & $\begin{array}{l}\text { Leo senex, aper, } \\
\text { taurus et asinus }\end{array}$ & Phaedr. 1.21 & $\begin{array}{l}\text { Alcmanic strophe: } \\
\text { hexameter + dactylic } \\
\text { tetrameter }\end{array}$ \\
\hline 10 & Vulpes et uva & Phaedr. 4.3 & $\begin{array}{l}\text { First Archilochean } \\
\text { strophe: hexameter + } \\
\text { hemiepes }\end{array}$ \\
\hline
\end{tabular}

${ }^{23}$ Poggi 1883 (as in n. 1), 307 (Ibid. 19-21): "Sibique adiunctos italos versus singulae / ibi tunc habuere, et italum quoque prologum / et lingua eadem pariter agendas gratias."

${ }^{24}$ In Boero's edition there is a misprint: we must replace the term "lupus" with "lepus", as is seen clearly in the fable. 


\begin{tabular}{|c|c|c|c|}
\hline App. II & Title & Source & New Metre \\
\hline 11 & $\begin{array}{l}\text { Est eadem, quae } \\
\text { supra, de vulpe et uva, } \\
\text { sed alio metro }\end{array}$ & Phaedr. 4.3 & Hexameters \\
\hline 12 & $\begin{array}{l}\text { Est eadem de vulpe } \\
\text { et uva, sed longe } \\
\text { pressior }\end{array}$ & Phaedr. 4.3 & Hexameters \\
\hline 13 & $\begin{array}{l}\text { Asinus ad senem } \\
\text { pastorem }\end{array}$ & Phaedr. 1.15 & Hexameters \\
\hline 14 & Mons parturiens & Phaedr. 4.24 & Hexameters \\
\hline 15 & Equus et cervus & Hor. Ep. 10.1 & $\begin{array}{l}\text { Fourth Asclepiadean } \\
\text { strophe: Glyconic line } \\
\text { + First Asclepiadean }\end{array}$ \\
\hline
\end{tabular}

As can be deduced from his own words, Poggi's interest in fable as a literary genre probably originated as a result of the use of Phaedrus in the classroom. ${ }^{25}$ We have seen how Poggi used Phaedrus' fables as the basis for his rhetorical-literary exercises, thus connecting with a tradition that goes back to Aphthonius' Progymnasmata, where, among many others, an exercise in amplification of a fable is transmitted. ${ }^{26}$ The Jesuits will continue this ancient tradition in their Humanities and Rhetoric classes. ${ }^{27}$

${ }^{25}$ After the rediscovery of Phaedrus at the beginning of the 17th century (his editio princeps dates from 1596), the Roman fabulist gradually displaced Aesop's Latin translators and became a key author in the didactic programme of the Jesuits. Popular collections of fables from the beginning of the 17th century, such as the one published in Hanau (Apologi seu fabellae Aesopicae Graeco ac Latino carmine prosaque redditae [...] [Hanoviae, 1603]) or the one prepared by Isaac Nevelet (Mythologia Aesopica [...] [Francofurti, 1611]) made Phaedrus' fables known to a wider readership. Already in the 18th century, the importance of Phaedrus in the Ratio studiorum became incontestable. Cf. F.J. Idiáquez, Prácticas e industrias para promover las Letras Humanas (Villagarcía, 1758), 42-43: "Después que la Compañía formó sus reglas, se averiguó que Fedro era el verdadero autor de las fábulas, que ahora corren con su nombre, y por esta razón se le ha dado entrada en nuestras clases."

${ }^{26}$ Cf. Aphthon. Progymn. 1 (ed. L. Spengel, 21).

27 The rhetorical amplification of a given fable, following the model of the Progymnasmata, was a common exercise in the Jesuit schools of the 16th and 17th centuries. An illustrative example of this type of school exercise is analyzed by V. Pérez Custodio, "La amplificación retórica de la fábula del asno y la raposa en el ms. 6513 de la Biblioteca Nacional de España”, Humanitas 72 (2018), 113142 . 
In fact, the Aesopic fable in the hands of the Jesuits became an appropriate vehicle for rhetorical exercises on amplification. In this context, Poggi, for example, offers in Appendix I three versions of the fable of "The Fox and the Grapes" in different sizes and metrical structures. ${ }^{28}$ The Italian Jesuit himself clarifies the didactic intentionality and the rhetorical function of these variations on the same story:

quae [i.e. carmina] hic addo et quae Faventiae, poesim dum docerem, stans uno in pede dictavi alumno, qui in paucis carissimus erat mi tunc, Simoni Sangeorgio, exemplis artem eum docturus, qua ex metro in metrum verti aliena possint carmina, seu pressius seu fusius id quis exequi amet velitque. ${ }^{29}$

The Jesuit explains that his exercise consisted not only in transforming the metrical structure of the apologue but also in retelling a story in a broader way ("fusius") or in a more concise way ("pressius").

This type of exercise would have been very common in Jesuit schools during the seventeenth and eighteenth centuries, since the Ratio studiorum of 1599 included Aesop (and his Latin translations) in the selection of authors scheduled for the highest level of the Greek grammar class. This fact ensured the presence of the Greek fabulist (and of his Latin reelaborations) in the syllabus of Jesuit schools, the most influential training centres of the late Renaissance.

\section{Poggi's Fables and their Sources}

As we shall see, Phaedrus is the primary source for Simone Poggi's collection of fables. The election of the iambic senarii for his poems makes clear his dependence on the Latin fabulist. But he is not innovative on this point, since other poets such as the French Jesuits Jean Commire

${ }^{28}$ Poggi 1883 (as in n. 1), 318-325.

${ }^{29}$ Poggi 1883 (as in n. 1), 323 (Nimesius iterum lectori, 7-14): "I add here the poems that, while I was teaching poetry in Faenza, I effortlessly dictated to my student Simone Sangiorgio, dear to me like few others, to teach him with examples the art of transforming other people's poems from one meter to another in a more concise way or in a more amplifying way, according to the wishes and preferences of each one." 
(1625-1702) or Gabriel François Le Jay (1657-1734) had already adopted the iambic senarii as the usual meter in their fables. ${ }^{30}$

In 1.2 of the prologue to book 1 our author acknowledges following in the footsteps of Phaedrus, although he decides not to emulate him or compete with him for fear of falling into ridicule. Obviously, he is alluding to two fables from Phaedrus: 1.24 on the Frog who tried to imitate the Cow and 4.24 on the Mountain in labour:

Dum fabulas me versibus senariis

polire hic cernis, lector, et Phaedrum sequi, genio indulgere me tantum credas meo, non invidere illius famae aut aemulo conatu velle quoque cum illo de gloria canendo decertare. Si hoc vellem, mihi dixisset ille vel de ranae amentia, vel de ridiculo montis partu fabulam. ${ }^{31}$

In these introductory lines of Poggi there are echoes of Phaedrus himself in his prologue to book 1 (1 Prol. 1-2) and even of Lucretius in his praise of Epicurus (Lucr. DRN 3.3-6). This same fear of being compared with Phaedrus makes other Neo-Latin poets avoid reworking the apologues of the Roman fabulist. We see this, for example, in the Liber fabularum that Gabriel Le Jay includes in his famous Bibliotheca rhetorum (1726). In the preliminary "admonitio" the French Jesuit affirms that, although he tries to imitate Phaedrus' modus fabulandi and emulate his simplicity and his

${ }^{30}$ From the first editions of his Carmina, Commire included among his poems a group of fables written in iambic senarii in imitation of those of Phaedrus. Among his fables, he even inserted a poem dedicated to iambic rhythm to encourage his friend Pererius to publish a fable that he had promised him some time ago ("Ad Iambum, ut Carolum Pererium virum clarissimum admoneat fabulam iamdudum promissam in lucem edere", 1-6): "Amoenitatis et leporis arbiter, / venuste Iambe, si quid ambo candidis / quod et placeret, utile et simul foret, / Huetio probante, lusimus iocis, / Pereri, amica, quaeso, nota nam via est, / adire tecta concito velis gradu." Cf. Joannis Commirii Carmina. Tertia editio auctior et emendatior (Lutetiae Parisiorum, 1689), 305.

${ }^{31}$ Poggi 1883 (as in n. 1), 3: "O reader, although you see me here polishing the fables in iambic senarii and following in the footsteps of Phaedrus, you must know that I give myself only to my genius, that I do not envy his fame nor intend to rival or compete with him for poetic glory. If I intended such a thing, he could have told me the fable about the madness of the frog or about the ridiculous product of a mountain in labour". 
grace, he will avoid dealing with the same fables of Phaedrus for fear of appearing like a pygmy in front of a giant:

Ipsum Augusti libertum in narrandis fabulis imitandum nobis proposuimus, et nativam eiusdem simplicitatem ac gratiam pro modulo nostro conati sumus aemulari. Caeterum ne commissus cum Gigante Pygmaeus videretur, abstinendum consulto duximus ab iis fabellis, quas Phaedrus ipse exornandas suscepit. ${ }^{32}$

Later, Poggi will use the Aesopic story of The Fox that Had Never Seen a Lion (Vulpes et leo $2.7=$ Aes. 10 Perry $=42$ Chambry $=39$ Halm) to explain the evolution of his own relationship with the Roman fabulist. This fable is about the fox that, on seeing the lion for the first time, was frightened almost to death; the second time he saw one, he was still frightened but not so much as before; on the third occasion the Fox became so bold as to approach the lion and talk with him:

Vulpes, quae non leones ante viderat, unum quum forte ex his vidisset, territa fuit ita, ut, spiritu nimia formidine sibi intercluso, pene vita excesserit.

Dies post aliquot eundem vidit obvium sibi venire, seque abscondit ea quidem, ac timuit, sed minor fuit multo hic metus primo illo. Ostendit tandem ei se tertio iubatus idem silvarum rex et adeo omnem pavorem haec corde tunc excusserat, ut eum primo sit ausu adire et alloqui, cumque illo dein confabulari et ludere. ${ }^{33}$

After his version of the fable, Poggi ends his poem with the following epimythium: "iis, quae nos terruerant, usu assuescimus". ${ }^{34}$ Just after this fable, in a poem entitled Poeta, the Jesuit asserts his independence from his sources (4-7):

32 P. G. F. Le Jay, Bibliotheca rhetorum, praecepta et exempla complectens quae ad poeticam facultatem pertinent. Tomus quartus [...] (Ingolstadii, 1726), 353.

${ }^{33}$ Poggi 1883 (as in n. 1), 46.

${ }^{34}$ Poggi 1883 (as in n. 1), 46: "through repetition we get accustomed to the cause of our fears." 
Mihi obtrectare si censor aliquis velit, hoc teneat primum: libere me scribere, et qui sit liber, aut respuat aut eligat, sequi nil unquam, nisi libitum arbitrii sui. ${ }^{35}$

He also states (12-16) that he excluded from his book the fables that Phaedrus and other fabulists "had embellished" with iambic senarii, the meter employed by Poggi:

Sciat libello ab hoc illas me excludere, quas vel Phaedrum vel alium quemquam noverim his, queis hic utor, iam polisse versibus.

Easque dein me quaerere, quas rebus meis

mihique sentio melius alludere. ${ }^{36}$

One exception is the above mentioned fable of The Fox that Had Never Seen a Lion: although Gabriele Faerno had embellished it with the same metrical structure used by Phaedrus, Poggi did not hesitate to dress it with the ornaments of iambic rhythm, in order to make it look even more splendid. ${ }^{37} \mathrm{He}$ ends by comparing his attitude to Aesop's and Phaedrus' fables with the attitude of the fox towards the lion (26-33):

35 Poggi 1883 (as in n. 1), 47: "if any censor wants to criticize me, I want him to keep this in mind first: that I write freely and that he who is free to choose or reject, pursues nothing unless it pleases him." Poggi probably knew and used the Latin translations and re-elaborations of Aesop that were circulating in the 16th and 17th centuries. In this fable, for example, we recognize certain echoes of Lorenzo Valla's Latin translation (confabulata: cf. M.P. Pillolla [ed.], Laurentius Vallensis, Fabulae Aesopicae [Genova, 2003], 116-117) and also of its adaptation in Camerarius' fable collection (viderat; exterrita; pene moreretur formidine; usu et consuetudine: cf. Aesopi Phrygis fabularum celeberrimi autoris Vita. Fabellae Aesopicae plures quadringentis [...] pertextae a Ioachimo Camerario [Tubingae, 1538], f. 40r).

${ }^{36}$ Poggi 1883 (as in n. 1), 47: "Let [the critic] know that I exclude from this little book the fables that I know Phaedrus or anyone else has already polished with the same metrical rhythms that I use here, and then I look for the fables that best suit me and my interests."

37 The influence of Faerno's fab. 18 on Poggi's fable 2.7 seems clear and can also be verified through the use of a very similar vocabulary. Cf. Fabellae centum [...] a Gab. Faerno Cremonensi carminibus explicatae (Romae, 1563), 18; and L. Marcozzi (ed., tr.), Gabriele Faerno, Le favole (Roma, 2005), 304-305 (2-4): "[...] prae metu vulpes fere / animam reliquit; viso eo rursum obvio, / timuit quidem illa, sed minus multo tamen." 
Nec erit, puto, qui neget optari eam mihi sat pulchre posse, qui iam Aesopi lusibus Phaedrique assuevi cumque utroque fabulor iocansque versor, postquam primo territus eorum adspectu et ratus intractabiles et arduos nimis illis desperaveram vel admisceri posse colludentibus vel tantum, quidquid eniterer, accedere. ${ }^{38}$

As seen in the mentioned apologue, through frequent contact with the models Poggi (just like his contemporaries) becomes gradually less faithful to them.

As we can see, the Jesuit from Bologna, following the example of Phaedrus, uses his prologues, epilogues and programmatic fables to give clues about his sources and literary interests, as well as about autobiographical issues. ${ }^{39}$

On the other hand, just as Phaedrus did (he is also his main model in this aspect), our fabulist progressively marks his differences with his models, until he declares himself freed from their influence. As Phaedrus considered in the prologue to book 5 that his debt to Aesop had been settled, ${ }^{40}$ in the same way Poggi in the prologue to book 5 confesses that, at first, he only aspired to imitate his models, Phaedrus and Aesop; but, progressively, he went a long way off their path; now he says that the only reason why he persists in composing fables is his own pleasure:

Et quo procedo magis,

eo magis ab illius recta semita

divaricari et distrahi me sentio.

[...]

Quia, quamvis nemini placuero, dum legar, dum scribo et otium fugio, placeo mihi. ${ }^{41}$

38 Poggi 1883 (as in n. 1), 47: "There will be, I think, no one to say that I cannot rightly choose this fable, I, who got used to the games of Phaedrus and Aesop and with both of them I talk and merrily treat, after I, terrified at first sight of them and believing them to be untreatable and too lofty, had lost all hope of being able to mingle in their games or of getting as close as I could."

39 See n. 14.

${ }^{40}$ Phaedr. 5 Prol. 1-3: "Aesopi nomen sicubi interposuero, / cui reddidi iam pridem quicquid debui, / auctoritatis esse scito gratia."

${ }^{41}$ Poggi 1883 (as in n. 1), 149: 6 Prol. 8-10 and 15-16. 
Our fabulist concludes his relationship with Phaedrus in book 7. In its prologue he acknowledges that he has accepted the challenge of composing in persona Phaedri the fables that the Roman writer could not write. Poggi alludes to an old and very influential literary topos; he states that Phaedrus appeared to him in dreams dictating to him the fables of this book and ordering him to polish them in iambic senarii (14-19):

mi noctis tempore

videndum se Phaedrum dedisse, et fabulas

has omnes enarrasse, quae huic septimo

committo libro, et imperasse ut versibus

illis polirem, quibus eum, dum viveret,

polisse noram caeteras omnes suas. ${ }^{42}$

These features may serve as a small sample of Poggi's dependence on Phaedrus, as it would be endless to make an exhaustive catalogue of the deep impact of Phaedrus' ideas and lexical reminiscences on the apologues of the Italian Jesuit. ${ }^{43}$

The other great source of Poggi's fables is what he calls Aesop. In fact, the name of Aesop is often associated with Phaedrus, and they are both the only fabulists expressly named in Poggi's fables, except, as indicated, a mention of the sixteenth-century Italian fabulist Gabriele Faerno. ${ }^{44}$ As I have pointed out, although he does not explicitly mention them, it is also likely that Poggi knew not only the Greek version but also some of the Latin translations and re-elaborations of the Aesopic fables.

${ }^{42}$ Poggi 1883 (as in n. 1), 185: "[I will say that] Phaedrus appeared to me in the middle of the night and told me all these fables, which I gather in this seventh book, and ordered me to polish them with these same verses with which I knew that he, while he was alive, had polished all the other fables."

${ }^{43}$ Another evidence of the profound influence of the Phaedrian lexicon on the fables of the Italian Jesuit is the fact that, on at least two occasions, Poggi uses the form "auritulus", only attested in Phaedr. 1.11.6. Cf. Poggi 1883 (as in n. 1), 260 and 326.

${ }^{44}$ Cf. Poggi 1883 (as in n. 1), 47. On Faerno's Latin fables and how they adapted the Aesopic tradition, see J.C. Miralles Maldonado, "Traductio and imitatio in Faerno's Neo-Latin fables", Humanistica Lovaniensia 51 (2002), 123 152. 
As, according to Poggi himself, ${ }^{45}$ he had been criticized for calling "Aesopic" the fables of book 1 , which were, in fact, all of his own invention, he decided that in the next two books the fables would not only be Aesopic but also from Aesop. Thus, Poggi devotes books 2 and 3 (which contain 15 fables each) to recreate apologues drawn from Aesop. Obviously, although these fables have their origin in the Aesopic collection, our poet adapts them with great freedom, making many innovations of his own in retelling them. Thus, Poggi sometimes distances himself from his model in the interpretation and moral application of the story. We see, for example, how, at times, Poggi openly disagrees with Aesop's morals or proposes conclusions totally different from those of Aesop. We can see this in fables 3.9 (Cochleae et rustici filius: Aes. 54 Perry = 172 Chambry = 214 Halm), 3.10 (Asinus et ranae: Aes. 189 Perry = 271 Chambry = 327 Halm) or 3.15 (Iactator audientium in corona: Aes. 33 Perry $=51$ Chambry $=203$ Halm), among others.

Indeed, although Poggi claims that in books 2 and 3 all the fables are taken from Aesop, his assertion is not entirely true. Often, the Jesuit takes as a starting point a well-known fable of Aesop, and then he derives from it other stories that emerge as new branches of the Aesopic tradition. Thus, for example, Poggi's fable 2.2. is an amplification of the wellknown Aesopic story The Jackdaw and the Pigeons (Aes. 129 Perry = 163 Chambry $=201 \mathrm{~b}$ Halm). By continuing the story begun in the previous fable, our poet composes a second (2.3) and a third (2.4) fable, which emerge as new shoots, as new branches (surculi) of the Aesopic fable. This compositional technique is, as we shall see below, one of the distinguishing features of Poggi's apologues.

This same procedure can be observed in other fables, such as 3.5 (Sus et canis) inspired by Aesop (Aes. 223 Perry = 342 Chambry = 409 Halm); from this trunk Poggi extracts three new branches or variants: poems 3.6, 3.7 and 3.8. The fabulist himself speaks about his modus operandi:

45 Poggi 1883 (as in n. 1), 35 (2 Prol. 116-120): "In primo eo libro et reliquis sequentibus, / omnes quidem fabellae erant Aesopiae, / at nulla Aesopi, et sicubi eius inclytum / interposueram nomen, id egeram unice, / ut Phaedrus olim, auctoritatis gratia”. Once again, Poggi borrows Phaedrus' own words (5 Prol. 13) to defend himself against criticism. 
Novi ex hac vero en tres erumpunt surculi, quos cerne tribus in fabulis sequentibus, tribus sed non illepidis, nec longissimis. ${ }^{46}$

The Italian fabulist not only knows the Collectio Augustana but also seems to be familiar with the text of the Vita Aesopi. Indeed, after offering a particular version of the Aesopic apologue 177 Perry (= 258 Chambry $=310 \mathrm{Halm}$ ) in his fab. 3.1 (Navis ex alto ad littus veniens et viator), Poggi alludes to the similar story told by Aesop to the Delphians (Vita Aesopi 125) and the tragic consequences it brought to him:

Suo haec Auctori fabula fatalis fuit, datus nam praeceps alta ex rupe est Delphica, hanc quia narravit eius urbis civibus.

Et audeo hanc recantare ego Faventiae?

Audeo nec mihi timeo futuram noxiam.

Ille hoc commento eos cives perstringere ceu viles voluit et carentes dotibus, queis tota ornatos praedicabat Graecia.

Ego hanc cui scribo? Mihi tantum et meis libellis hisce. ${ }^{47}$

Another important source of inspiration in Poggi's latest books is the Bible, in particular the text of the Latin Vulgate. Thus, fable 6.11 (The Arrogance of the Thistle of Lebanon) and fable 6.12 (The Bush as Tyrant of the Trees) refer to the corresponding biblical apologues transmitted in 2 Kings 14.9-10 and Judges 9.8-16, respectively. These are the only biblical stories that seem to fit the classical structure of the ancient fable.

Specifically, the apologue 6.12 of Poggi amplifies in an extensive poem in iambic senarii (64 verses) the story of Ioathan blaming the men of Shechem for having chosen as king Abimelech, the murderer of his brothers. At the beginning of the poem there are echoes or lexical remi-

46 Poggi 1883 (as in n. 1), 63 (3.5, 16-18): "But here three new branches emerge from this fable. Note them in the following three fables, three fables, however, that are not without grace and are not very long."

47 Poggi 1883 (as in n. 1), 59 (3.1 Poeta 1-10): "This fable proved fatal to its author, for he was forced to fall from a high rock in Delphi for having told it to the citizens of that city. And do I dare tell it again in Faenza? I dare, and I do not fear future harm. With this tale, he wanted to censure the Delphians as vile and lacking in those virtues, which all Greece proclaimed they were well equipped with. For whom do I write it? Only for myself and for these little books of mine." 
niscences of Phaedrus (Phaedr. 3.17.1: "Olim quas vellent" / 6.12.5: "Olim quum vellent"). Then, the Jesuit follows closely the text of the Latin Vulgate, as can be seen from many lexical borrowings: 6.12.8: "veni et impera" / Iud. 9.12: "veni et impera nobis"; 6.12.9-10: "Qui possum, dixit illa, meam pinguedinem / deserere, qua et homines utuntur et Dii?" / Iud. 9.9: "numquid possum deserere pinguedinem meam, qua et dii utuntur et homines?"; 6.12.14-16: "meam dulcedinem / cur deseram, respondit, et suavissimos / quos habeo fructus?" / Iud. 9.11: "numquid possum deserere dulcedinem meam fructusque suavissimos?", etc. ${ }^{48}$

Later on, in a fable named Poeta, after fable 9.9, Poggi recalls these two biblical fables to conclude that it is licit to mix the sacred with the profane, when these profane materials are useful to give prudent counsels, praising virtues and reproving vices:

Profanis sacra non miscenda dixeris?

Ast num profanum sit, quod sacris consonat, et quod prudenti vitam consilio monens, nil praeter laudat, quam quae Virtus approbet, et sola continenter vitia exsibilat? ${ }^{49}$

Then, taking as a starting point some mentions of animals in the Bible, Poggi develops new apologues from these allusions. Thus, fable 9.10 is inspired by a passage from the prophet Ezekiel 19.2-4; fab. 9.11 is drawn from Ez. 19.5-9; and fab. 9.12 from Ez. 19.10-14. On the other hand, fables 9.13 and 9.14 are based on a quotation from Psalm 80 (79), 14. Images from the Old Testament are also recreated in fable 9.15, which is inspired by a passage from the Song of Songs (2.15), and in fable 9.16, which reworks an episode of the life of Samson narrated in the book of

48 This fable was often mentioned by humanists and, although it was not transmitted in the main fable collections of the Renaissance (Brant-Steinhöwel, Dorp, Camerarius, etc.), it enjoyed a great reception. See, among many others, Faerno's fab. 93 Arbores et rhamnus. On the relationship of this biblical parable to the Aesopic tradition (in particular to Aes. 262 Perry = 252 Chambry), see Z. Margulies, "Aesop and Jotham's Parable of the Trees (Judges 9: 8-15)", Vetus Testamentum 69.1 (2019), 81-94.

49 Poggi 1883 (as in n. 1), 261 (9.9 Poeta 12-16): "Would you say that the profane should not be mixed with the sacred? But can be considered profane that which is in harmony with the sacred, and that which, giving prudent advice for life, praises nothing but what Virtue approves of, and constantly rejects only the vices?" Once again the allusion to the prologue of Phaedrus' book 1 is clear (v. 4): "et quod prudenti vitam consilio monet." 
Judges 15.4-5. Even the parables of Jesus himself about the lost sheep (Luke 15.6) and the blind man who leads another blind man (Matthew 15.14) constitute the plot of Poggi's fables 9.19 and 9.20, respectively.

Finally, one might ask whether Poggi, in composing his fables, also draws inspiration from modern fable collections written in the vernacular as that of La Fontaine. Indeed, certain structural and lexical coincidences between Poggi's fab. 3.12 (Culex et leo) [= Aes. 255 Perry = 188 Chambry] and La Fontaine's fab. 2.9 (Le lion et le moucheron) suggest that perhaps our author could have been inspired in this case by the French fabulist, whose works he might have known.

To illustrate these correspondences, let us look at two passages from their works:

\section{La Fontaine's fab. 2.9.19-21}

Un avorton de mouche en cent

lieux le harcelle:

Tantôt pique l'échine, et tantôt

le museau

Tantôt entre au fond du naseau. ${ }^{50}$

\section{Poggi's fab. 3.12.4-6}

Eique nasum primo, dein aurem ferit;

atque inde quam celerrime circumvolans,

alia frementi mille infligit vulnera.

However, as we pointed out, most of the fables that make up Poggi's collection are originals by the Italian author. From the prologues to books 1 and $2,{ }^{51}$ the Jesuit reaffirms his creative freedom, which are outlined and deepened throughout his collection. In the brief prologue to book 8 , he summarizes the reasons that lead him to take up again the composition of fables, long interrupted: leisure, passion for writing and the abundance of themes. Indeed, here and elsewhere he insists that the vices and folly of men offer him inexhaustible material for his fables:

Ad intermissas iamdiu me fabulas redire, invitum quamvis, cogit otium et scribendi libido, et rerum copia. Novisque semper vitiis incurrentibus, quis saxeus tam sit, quis sit tam ferreus, ut teneat se, nec quae ridicule aut impie stulti peccant, si apertis ac veris nequit

50 Cf. J. La Fontaine, Fables, préface et commentaires de P. Clarac (Paris, 1972), 54; and Poggi 1883, 73.

${ }^{51}$ Cf. Poggi 1883 (as in n. 1), 3 and 35. 
proferre in lucem criminationibus, ea fictis saltem non perstringat fabulis? ${ }^{52}$

\section{How Does Poggi Adapt the Fabulistic Tradition (Aesop and Phae- drus) to Create New Fables?}

To illustrate how Poggi adapts and recreates the fabulistic tradition to create new fables, I will take his fable 4.1 Venti regem petentes as an example. As can be easily deduced from the title, our author takes as primary source the famous fable 1.2 of Phaedrus (Aes. 44 Perry $=66$ Chambry $=76 \mathrm{Halm}$ ) about the frogs that asked Jupiter to grant them a king: Ranae regem petierunt. He not only imitates the structure of Phaedrus' apologue but even borrows some of his verses. This is how Poggi's story begins (4.1.1): "Venti vagantes liberis volatibus", a clear allusion to the beginning of Phaedrus' fable (1.2.10): "Ranae vagantes liberis paludibus". The Jesuit replaces the frogs of the traditional fable with the winds that ask Jupiter for a king. Contrary to what they expect, the father of the gods gives them as king the god Eolus who submits them to captivity. In the following fable, 4.2 (Aura et rana), the breeze (aura) laments its fate. Then a frog, who has heard the breeze's moans, tells him what happened to them when they asked Jupiter for a king: how the god, at their insistence and after their protests because they were not satisfied with the first king sent to them $(\mathrm{a} \log )$, finally, sent them a hydra or water snake that devoured them with its "cruel teeth". ${ }^{33}$ So, the frog advises him, warned by his own example, not to dare to complain:

Tace ergo tandem, quodque prudentes decet, tua ferre discas, aliena inspiciens mala. ${ }^{54}$

52 Poggi 1883 (as in n. 1), 221 (8 Prol.): "Leisure, the passion for writing and the abundance of subjects force me, to my regret, to take up again the composition of fables, which I abandoned long ago. And, since new vices keep appearing, who is so made of stone, who is so made of iron that he can refrain from telling the faults that fools commit in a ridiculous and impious way, at least with feigned fables, if he cannot bring them to light with frank and truthful accusations?"

53 The expression "dente [...] aspero" from Poggi's fable 4.2.10 is, again, a clear allusion to Phaedr. 1.2.24: "dente aspero".

${ }^{54}$ Poggi 1883 (as in n. 1), 88 (4.2.12-13): "So be quiet at once and, as the wise should do, learn to bear your own troubles, when you see the troubles of others." 
In fable 4.3, Poggi reminds the reader that in other versions of the apologue the hydra is replaced by a stork or a crane, which cause similar havoc among the frogs. However, the Italian fabulist prefers to follow Phaedrus' version and even makes Jupiter himself intervene to assert his choice against the versions where the crane or the stork becomes the protagonist. However, the aforementioned old variations of the story will serve to inspire Poggi to compose new fables where he continues to narrate the afflictions of the frogs attacked by other predators: I am referring to fables 4.4 (Rana et ciconia), 4.5 (Gruis et ranae) or 4.6 (Aves aliae quamplurimae ranis infestae). As can be seen, the different versions of the Aesopic story sometimes stimulate the creative capacity of the Italian Jesuit. ${ }^{55}$

The treatment of this group of stories, the first six fables of book 4, can serve to illustrate Simone Poggi's modus fabulandi. Often in the prologues, epilogues and other programmatic poems the fabulist alludes to his compositional methods. Thus, as we have already seen, he tells us how he uses certain old fables to derive new stories from them; for him these new stories are like young shoots or new branches (surculi) that are born from an old trunk. ${ }^{56}$

This tendency to chain two, three or more fables, characteristic of Poggi's modus fabulandi, will be accentuated from book 4 onwards. In book 4 he returns to the fables of his own invention. In fact, in the poem entitled Poeta that closes book 3, he declares his intention to maintain this practice and shows himself challenging his critics. He invites them to write their own fables without grouping them thematically or, at least, to read disorderly the ones he composed. ${ }^{57}$ Indeed, we observe how Poggi often joins groups of three or more fables, because they are associated by a similar theme, because some are a continuation of others or simply because they are linked by common protagonists (frogs, cats, birds, etc.), which serve as a transition between one fable and the next. Thus, for

55 On the interpretation of Phaedrus' fab. 1.2 and on its later variations, see E. Dicke, K. Grubmüller, Die Fabel des Mittelalters und der frühen Neuzeit. Ein Katalog der deutschen Versionen und ihrer lateinischen Entsprechungen (München, 1987), no. 162; F. Rodríguez Adrados, “'Las ranas pidiendo rey': origen y evolución de una fábula política", Emerita 52.1 (1984), 25-32; R.W. Brednich, "Frösche bitten um einem König", Enzyklopädie des Märchens, vol. 5 (Berlin - New York, NY, 1987), 408-410; and O. Zwierlein, "Jupiter und die Frösche", Hermes 117.2 (1989), 182-191.

${ }^{56}$ Poggi 1883 (as in n. 1), 63: 3.5.16-18.

${ }^{57}$ Poggi 1883 (as in n. 1), 81-83. 
example, as we already indicated, fable 2.2 (on the jackdaw and the pigeons) is continued and amplified through fables 2.3 and 2.4; and from fab. 3.5 (on the sow and the bitch that discuss their fertility) the Jesuit draws three different versions of this topic: $3.6,3.7$ and 3.8. Some fables from book 8 (fables 3 to 18) also share the same scenario, for they all take place at the council of animals, presided over by the lion king. Other large groups (and even entire books) are starred by the same type of animals: the frogs, for example, are the almost exclusive protagonists of book 4; many cats are hanging around book 5 (10-16) and birds play the predominant role in book 10 (11-20).

In poem 8.19 (Nimesius et amicus disputantes de sexdecim praecedentibus fabulis) a friend reproaches him for this concatenation of similar fables. In fact, in book 8 Poggi links thematically up to 16 fables. This practice is not attested among the ancient fabulists, in which varietas dominates. In his defence, the Italian fabulist considers, on the one hand, that Aesop and Phaedrus, whose works have only been preserved in a fragmentary way, could well have used this technique. On the other hand, the Jesuit conceives the fables as short dramatic scenes that conform according to his own words - a kind of "wild comedy" (8.19.19: "silvestrem comoediam"). ${ }^{58}$

Later on, in poem 9.12 (Poeta iterum) he will summarize with a fresh metaphor his improvised way of organizing fabulistic materials:

Mihi fabellae sunt cerasis simillimae:

assumere unam cupio, veniunt quindecim. ${ }^{59}$

In other words: "I have - he says - the same problem with fables as with cherries: I want to pick only one, but there are fifteen behind it".

\subsection{Peculiar Features and Achievements of Poggi's Fable Collection}

Our fabulist knows perfectly well the stylistic implications of this way of narrating, and the consequences of his narratological preferences. Thus, already in the prologue to book 4 he affirms without hesitation that his fables lack the iucunda brevitas and the rerum varietas of his models. Unlike them, he proposes more extensive stories and focuses on a smaller number of themes, although he hopes that the readers will find in his

${ }^{58}$ Poggi 1883 (as in n. 1), 244-246. Cf. Filosa 1952 (as in n. 2), 284.

${ }^{59}$ Poggi 1883 (as in n. 1), 266: 9.12 Poeta iterum 7-8. 
verses good advice and sentences that compensate for their efforts. Dealing with the moral utility of his apologues, the Jesuit alludes to the wellknown story of the Cock and the Pearl:

Et Gallus, ipso Aesopo ac Phaedro testibus, in sterquilino nonne gemmam repperit? ${ }^{60}$

On the other hand, as we have seen, ${ }^{61}$ the author himself is aware of his tendency to overabundance and prolixity, and he knows that these traits can produce a sense of satiety in the reader. ${ }^{62}$ Curiously, he exemplifies his stylistic options with the famous fable 3.4 (Vulpes iterum alia et leaena) about the lioness and the fox, inspired by Aesop (Aes. 257 Perry $=194$ Chambry $=240$ Halm). In this case, Poggi keeps the classical structure of the story: the fox criticizes the lioness for giving birth to only one cub at a time. The lioness defends herself by saying that, although she only gives birth to one cub at a time, that is a lion's cub. After repeating the classical epimythium which emphasizes the superiority of quality over quantity, our poet applies the moral advice to himself. This leads him to candidly acknowledge his own weaknesses as a poet seduced by overabundance:

Est vera, at, heu!, me terret haec sententia.

Me, qui ferax tam multa pango carmina,

totque imprimenda congero volumina,

neque interim, ea dum praeparo, sum sat anxius

de eorum dignitate et excellentia. ${ }^{63}$

Later, he tells the reader how a critic asked him to eliminate some verses from a fable, but he refused to do it. He does not want, he says, to make the same mistake as that woman who cut out a piece of cloth so much that she reduced it to a small handkerchief (fab. 6.6.7-9):

60 Poggi 1883 (as in n. 1), 86 (4 Prol. 28-29): "Did not the cock find a jewel in the stable, as Aesop and Phaedrus themselves testify?"

${ }^{61}$ Cf. Poggi 1883 (as in n. 1), 85.

${ }^{62}$ Cf. Poggi 1883 (as in n. 1), 82 (3.15 Poeta 20-21): "Eamque nauseam parere lectoribus / quibus variatione nil est dulcius". On the stylistic features of Poggi's fables, see Filosa 1952 (as in n. 2), 282.

63 Poggi 1883 (as in n. 1), 62 (3.4.13-17): "It is true, but alas, this thought terrifies me, who so abundantly compose many poems and accumulate so many volumes for publication, and sometimes, while I am preparing them, I am not too much concerned with their beauty and excellence." 
Et nos cavere docuit, ne paria viri, in nostra incauti dum lituras ducimus, exempla demus foemineae dementiae. ${ }^{64}$

In addition, as an amplification on this subject and to defend himself before his critics by arguing the danger of carrying out a too strict labor limae, he tells fable 6.7 on the blacksmith who filed an arrow (Faber limans spiculum):

Qui corrigit, sit parcus. Id negas? Probo.

Faber, polire lima dum vult spiculum, attrivit adeo, ut medium tandem fregerit. ${ }^{65}$

With this brief fable, he makes fun of those who are obsessed with brevity, while he shows his detractors that he too knows how to be brief, when he wants to. This highlights another of the characteristic features of his work: humour.

That humour, that bonhomie, is sometimes reflected in friendly fables, full of wise humanity, like fab. 8.20 on the thicket, the fig-pecker and the goldfinch (Dumetum, ficedula et carduelis), in which he shows himself indulgent with the vices of old age, which time reveals and which are probably his own vices as an old man:

Senectus, quidquid contra plures senserint, nobis non addit vitia, ea tantum detegit, quae occuluit ante vel iuventus florida vel fructuosa et utilis maturitas. ${ }^{66}$

Poggi's humour is often based on conceptual word games, to which he gives himself with passion. ${ }^{67} \mathrm{He}$ even composes some fables, that we could call "philological", in which the core of the story is concentrated on puns or linguistic wordplays. This is the case, for example, of the brief

${ }^{64}$ Poggi 1883 (as in n. 1), 158: "And this has taught us men to be careful not to show similar signs of female folly when we make corrections to the poems."

65 Poggi 1883 (as in n. 1), 159: "He who corrects, must be frugal. Do you think not? I will prove it to you. A blacksmith, while trying to sharpen the tip of an arrow, wore it out so much that he ended up breaking it in half."

${ }^{66}$ Poggi 1883 (as in n. 1), 246 (8.20.1-4): "Old age, contrary to what most people think, does not add vices to us, it only reveals those that flourishing youth or fruitful and useful maturity once kept hidden."

${ }^{67}$ Cf. Poggi 1883 (as in n. 1), 139 (5.9 Poeta 42): "immorari et immori." 
fable 6.16 Avarus de felibus, a kind of aetiological tale through which the author attempts to explain by a pseudo-etymological word game why avaricious men are so fond of cats:

Avarus feles omnes perditissime

amabat. Tanti amoris causas quaerere

coepere amici; at dum putabant unice

dilectas, qui domos purgarent muribus,

est fassus ideo sibi placere has maxime,

quia suam dum vocem eiulantes exprimunt,

nihil videntur dicere, quam meum, meum.

Scelestis hisce est nullum verbum gratius. ${ }^{68}$

The dominant presence of humorous features in his fables sometimes makes his poems turn into burlesque epigrams, as in fable 9.21 (Praecedentis parabolae ignarus lector), where, after having reworked a story (9.20) from the parable in St. Matthew's Gospel (15.14), our author makes fun of one who does not know the Latin language and who, on reading this passage: "Si caecus caeco ducatum praestet, ambo in foveam cadunt", interprets the expression "ducatum praestet" as meaning "he lends a ducat" (instead of "he leads, he guides").

Another remarkable feature of Poggi's fables is a strong feeling of solidarity with the kingdom of nature, which he knows not only from reading fables but also from his own observation: ${ }^{69}$

Lusciniam bufo, bufonem ipsum vipera

trahit glutitque. Id non hae nostrae fabulae

${ }^{68}$ Poggi 1883 (as in n. 1), 147 (5.16): “A miser loved all cats desperately. His friends one day asked him why he loved them so much; and although they thought they were especially dear to him because they cleaned the houses of mice, he confessed to them that he liked them above all for this reason, because, when they start their laments, they seem to say nothing but 'mine', 'mine'. And to these criminals no word is more pleasant".

${ }^{69}$ Cf. Filosa 1952 (as in n. 2), 282-283. 
tantum testantur, sed nos ipsi non semel in campis vidimus. ${ }^{70}$

In this same poem, which serves as an epilogue to fable 5.9, our poet discusses the universal circle of attractions and rejections that unites all natural beings. These natural forces, like love and hate, rule the universe. He bases his ideas on the physical theories of Pierre Gassendi and Isaac Newton, whom he expressly cites:
Atque his aeriis hic detectis vinculis attractionum quinam longus circulus hic est? Et paleas attrahente succino praeterea, et ferrum magnete, et grave quodlibet tellure, ut doctus asserit Gassendius, quin omnibus planetis et caelestibus globis uncis se mutuis trahentibus, disserte ut affirmare audet Newtonius. ${ }^{71}$

As we can see, our Jesuit seems to be familiar with the scientific advances of the seventeenth and eighteenth centuries.

However, what makes this collection all the more attractive is the fact that Poggi does not take himself too seriously as an artist and does not miss the opportunity to act as a severe critic of his own poetic work:

Lectores me, quos inter maluerint, locent.

Addi non renuam pessimis cantoribus. ${ }^{72}$

However, in spite of his sharp self-criticism, Poggi believes himself to be redeemed of all his sins by his love of poetry. His fable 7.7 (Luscinia et

70 Poggi 1883 (as in n. 1), 138 (5.9 Poeta 1-4): "The toad lures and devours the nightingale, the viper does the same with the toad itself. Not only do my fables testify to this, but I myself have seen it more than once in the fields." Poggi's words sound a little strange: it would be difficult, if not impossible, for him to contemplate a toad devouring a nightingale. In any case, one should probably not take Poggi's words too seriously, since the toad is often defined in his fables as a being with fantastic features, as a kind of "monstrum" with "taeterrimas / venenatas fauces": cf. Poggi 5.5, 6, 7, 8 and 9. For the traditional characteristics of the toad, see Ulyssis Aldrovandi [...] De quadrupedibus digitatis viviparis libri tres. De quadrupedibus digitatis oviparis libri duo (Bononiae, 1637), 607-620.

${ }^{71}$ Poggi 1883 (as in n. 1), 139 (5.9 Poeta 18-25).

72 Poggi 1883 (as in n. 1), 256 (10.4 Poeta 76-77): "Let the readers place me among those they prefer. I will not refuse to be included among the lousy poets." 
passer vulgo canarius), in which he compares Phaedrus and himself to a canary that sings only for the love of singing, unlike other birds like the nightingale (= Propertius) that sing only out of love or passion, is very illustrative in this respect (1-5):

Luscinia dixit passeri canario:

"Cur laetus anni quovis cantas tempore, ego dum tantum veris canto mensibus?"

Tunc ille: "Innato amore ego cantus cano;

tu contra mota foeminae cupidine." 73

Another example of his humour and self-critical spirit is offered in his prologue to book 10 . In it the fabulist appeals to the reader and tells him not to expect to find in this book a brilliant style or magnificent verses. If he does so, Poggi says, it will be the same for him as for those who are waiting to see how the mountain is giving birth. ${ }^{74}$ The Jesuit, playing with the meaning of his name (the Italian term poggio means "small hill, knoll"), identifies himself with a small mountain that is in labour. The aforementioned prologue concludes with the following lines:

Parturio hic ergo, ut ille primus, et meos

ipse etiam hic cieo gemitus; estque maxima

huiusce nostri partus expectatio.

Quid vero pariens et ego in lucem proferam?

Murem ridiculum, quod ne ulterius iam neges,

de Mure prima sit tantillo fabula. ${ }^{75}$

These last words will serve as a transition to the first fables of book 10, where mice play the leading role. In this way, Poggi once again intro-

73 Poggi 1883 (as in n. 1), 198: "A nightingale said to a canary: 'Why do you sing joyfully at any time of the year, while I only sing in the spring months?'. He replied: 'I sing out of innate love for singing, you, on the contrary, only moved by the desire for a woman."

${ }^{74}$ Cf. Phaedr. 4.24 (Mons parturiens). From this same fable Poggi himself makes a version in hexameters: App. 14.

75 Poggi 1883 (as in n. 1), 278 (10 Prol. 30-35): "So here I am in labour, like the other before me, and here I utter my own groans. There is an immense expectation for this birth of mine. But what am I going to give birth to? A ridiculous mouse. And let's make the first fable about a tiny mouse, so that you won't deny it anymore." 
duces, like bunches of cherries, a new series of fables, united by the same protagonist: the mouse, in this case.

\section{Conclusion}

In these lines I have tried to offer an overview of the Latin fables of the Jesuit Simone M. Poggi, highlighting his debts to the fabulistic tradition, but also underlining his personal contributions. In my opinion, Poggi is one of the most faithful imitators of the Roman fabulist. Nevertheless, the Italian Jesuit, following in the footsteps of Phaedrus, is also able to create some original fables, suitable for his time. With his aforementioned naivety our poet identifies himself with the flying ants of fable 7.20 (Formicae volantes). These ants, excited by the passion of flying, forget to gather food for the winter and end up dying of hunger. In the promythium of this fable Poggi proposes his moral reading of the apologue:

Cui mens apta est poeticis volatibus, superbit ille et eos plerumque despicit, quibus minus sit agilis ab Diis data.

Ut vero is tandem sapiat, quam subdo, lepidam legat sibique scriptam credat fabulam,

in qua me quoque pictum video, et doleo, at nimis

id sero, cum iam duodecim ab lustris volem. ${ }^{76}$

In these lines he confesses that he was already sixty years old when he reflects with some bitterness on the precarious life of the poet. It is easy to imagine Poggi spending the long summers of his maturity in the small town of Faenza, having as his only amusement the composition of poems. His passion for writing fables (he speaks about his "fervida libido fabulandi") ${ }^{77}$ could hardly relieve the bitter feeling of consuming his last days in vain. In these fables, which he both wanted and did not want to publish, Poggi has left us, like his admired Phaedrus, many clues or hidden

76 Poggi 1883 (as in n. 1), 216 (7.20.1-7): "He who has a mind fit for poetic flights is arrogant and often despises those to whom the gods gave a less agile mind. In short, to understand well this ingenious fable, which I add below, one should read it and believe that it was written for him. In it I too find myself reflected and suffer, but it is too late, for I have been flying around for sixty years now."

${ }^{77}$ Cf. Poggi 1883 (as in n. 1), 139 (5.9 Poeta 41). 
messages about his character and his literary interests. With my research I hope to have contributed to a better knowledge of Poggi and his poetic work.

Universidad de Murcia miralles@um.es 